\title{
The importance of challenging your diagnosis even in straightforward cases
}

\author{
Erik Alberto Maus \\ Department of Internal Medicine, University of Texas at Houston and Memorial Hermann Hospital, Houston, Texas, USA
}

Correspondence to Dr Erik Alberto Maus, Erik.A.Maus@uth.tmc.edu, mausratz@gmail.com

\begin{abstract}
Summary
The art of diagnosis consists in the recognition of signs and symptoms and their interpretation under the light of individual circumstances obtained from the patient's history. In medicine we encounter cases that are straightforward and cases that are complex as they are the result of a rare disease or of uncommon presentation of a common disorder. We present in this paper the case of a patient with a nonhealing traumatic wound to her shin, which after unsuccessful treatments was biopsied and an unexpected diagnosis of necrobiosis lipoidica diabeticorum was made. This led to the institution of disease-targeted wound care leading to complete resolution in a short period of time.
\end{abstract}

\section{BACKGROUND}

The majority of the patients seen in wound centres suffer from conditions that are relatively easy to diagnose. Although the distribution varies greatly from centre to centre, it would not be incorrect to say that over $90 \%$ of the ulcer aetiologies will fall under venous and arterial insufficiency, diabetic, pressure ulcers, traumatic and nonhealing surgical wounds. Clinical signs and symptoms help the clinician determine the cause in order to establish a treatment directed to the management of the underlying condition and not only of the wound itself.

While a detailed history and physical examination are the cornerstones to establish a diagnosis, frequently ancillary studies such as cultures, imaging studies and biopsies need to be incorporated in order to obtain more information.

Typically one could expect to see some degree of improvement of a chronic ulcer after a couple of weeks of educated wound care. Ulcers that fail to show this response need to be reassessed and the diagnosis must be challenged.

\section{CASE PRESENTATION}

A 52-year-old African-American woman with a history of sickle cell anaemia treated with hydroxyurea, controlled type II diabetes and hypertension presented with a nonhealing traumatic ulcer on the right anterior shin. The lesion developed after a cardboard box fell on her shin causing skin breakdown about 8 weeks prior to consultation. The ulcer had been managed with over-the-counter topical antibiotic ointment with no clinical improvement.

After examining the patient and performing the standard vascular screening tests (transcutaneous oxygen mapping), it was considered that the aetiology of the ulcer was clearly trauma and that the underlying contributing factors that led to poor healing were tobacco use, her sickle cell anaemia and the use of hydroxyurea (figure 1).
The patient was advised to quit smoking and to adhere to her diabetic diet. Hydroxyurea was discontinued after discussing with her haematologist and she was started on a series of wound therapies consisting of debridements, use of antibacterial dressings, collagenase ointment, moisture control and the use of a porcine small intestine submucosa acellular wound matrix (Oasis). Despite all efforts the ulcer did not show any significant improvement at 8 weeks. At that time the decision was made to challenge our original diagnosis and a punch biopsy of the ulcer edge was obtained. The pathological diagnosis was necrobiosis lipoidica diabeticorum (NLD).

After reviewing the biopsy results the patient was started on topical Tacrolimus $0.1 \%$ ointment, ${ }^{1}$ which led to rapid improvement with complete resolution of the ulcer in about 8 weeks (figure 2). She experienced a slight recurrence after discontinuation of Tacrolimus, which promptly healed after she restarted the medication.

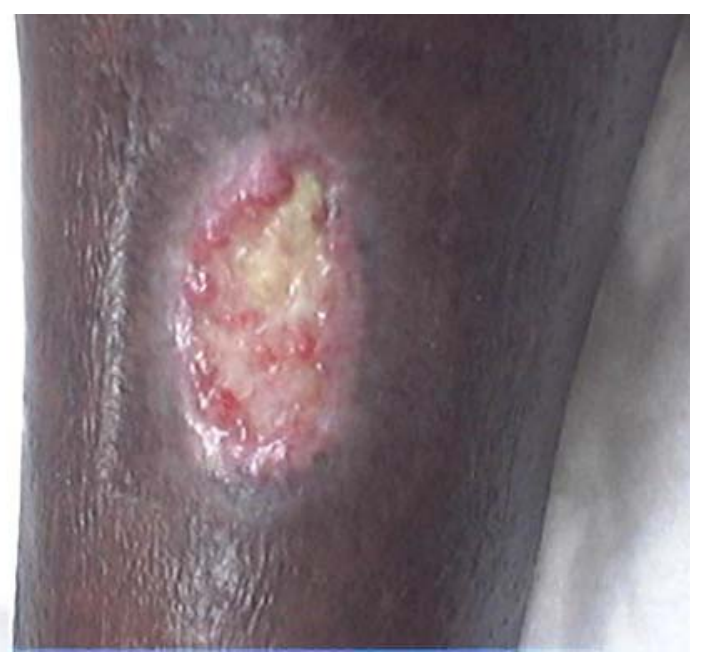

Figure 1 Ulcer at presentation. 


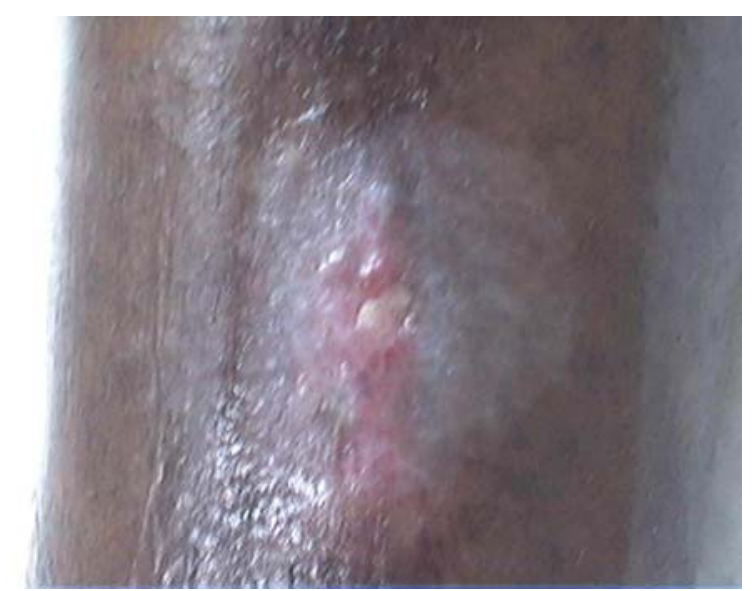

Figure 2 Ulcer almost healed at 2 weeks of therapy with topical Tacrolimus.

\section{INVESTIGATIONS}

Skin biopsy.

\section{DIFFERENTIAL DIAGNOSIS}

Venous and arterial insufficiency ulcers, sickle cell ulcer, medication-induced ulceration, ecthyma, atypical fungal or mycobacterial infections, etc.

\section{TREATMENT}

Topical Tacrolimus $0.1 \%$ ointment.

\section{OUTCOME AND FOLLOW-UP}

The ulcer showed rapid improvement with complete healing in about 8 weeks.

\section{DISCUSSION}

In this patient the primary and secondary diagnoses seemed logical from a historical and clinical perspectives; however, it required challenging of the diagnosis to establish the aetiology and to institute specific care. While all wounds require basic wound care consisting of cleansing, debridement and adequate dressings (exceptions for debridement exist in pyoderma gangrenosum and ischaemic lesions) there are specific treatments that need to be provided based on the aetiology. Venous stasis ulcers, for example, require compression, arterial ulcers revascularisation, neuropathic and pressure ulcers offloading.

This patient had a straightforward history: trauma to the leg in a patient with sickle cell anaemia. This patient was additionally on hydroxyurea, which is known to cause or predispose to ulcerations. ${ }^{2}$ Sickle cell ulcers are among the most difficult ulcers to heal and they usually develop after minor trauma. NLD is a relatively uncommon disorder of collagen degeneration with a granulomatous response, thickening of blood vessel walls and fat deposition. The main complication of the disease is ulceration, usually occurring after trauma. NLD may be associated with diabetes mellitus; however, $50 \%$ of cases occur in non-diabetic patients. The condition is generally characterised by the development of brownish plaques in the lower extremities, but this patient was not aware of having any of such lesions prior to her injury and there were no other lesions found on her examination. It was an unfortunate coincidence that the cardboard box fell exactly on a skin area previously affected by NLD. While not all ulcers need to be biopsied originally, we need to keep an open mind and consider pathological examination in ulcers that fail to respond after the institution of adequate wound care practices. Suspicious lesions should of course be biopsied early. Challenging the diagnosis should always be entertained when the expected results are not accomplished. Recognising diagnostic errors does not undermine our reputation as clinicians but allows us to learn for the future and improve our practices.

Learning points

- The obvious is not always that obvious.

- Maintain an open mind to explore other possibilities.

- Be humble to recognise your shortcomings.

- Skin biopsies, while invasive, represent a low-to-moderate risk and can provide invaluable information.

- Challenge your diagnosis if you do not see the expected results.

\section{Competing interests None.}

Patient consent Obtained.

\section{REFERENCES}

1. Mirkamali A, Carbonnelle-Puscian A, Bagot M. [Ulcerated necrobiosis lipoidica: successful treatment with topical tacrolimus and hydroxychlorochine]. Ann Dermatol Venereol 2010;137:561-2.

2. Vélez A, García-Aranda JM, Moreno JC. Hydroxyurea-induced leg ulcers: is macroerythrocytosis a pathogenic factor? J Eur Adad Dermatol Venereol 1999;12:243-4. 


\section{BMJ Case Reports}

This pdf has been created automatically from the final edited text and images.

Copyright 2012 BMJ Publishing Group. All rights reserved. For permission to reuse any of this content visit http://group.bmj.com/group/rights-licensing/permissions.

BMJ Case Report Fellows may re-use this article for personal use and teaching without any further permission.

Please cite this article as follows (you will need to access the article online to obtain the date of publication).

Maus EA. The importance of challenging your diagnosis even in straightforward cases. BMJ Case Reports 2012;10.1136/bcr-2012-006337, Published XXX

Become a Fellow of BMJ Case Reports today and you can:

- Submit as many cases as you like

- Enjoy fast sympathetic peer review and rapid publication of accepted articles

Access all the published articles

- Re-use any of the published material for personal use and teaching without further permission

For information on Institutional Fellowships contact consortiasales@bmjgroup.com

Visit casereports.bmj.com for more articles like this and to become a Fellow 